\section{Zagury report censures NIH}

Washington

THE US National Institutes of Health (NIH) failed to ensure the safety of human subjects in AIDS vaccine and immunotherapy trials that were led by the controversial French AIDS researcher Daniel Zagury and involved researchers from the institutes' Bethesda campus. That is the conclusion of a report released last week by the NIH Office for Protection from Research Risks (OPRR).

The report found a "disjointed, compartmentalized system" at NIH for protecting human subjects, and it gives NIH until mid-September to put matters right.

The OPRR investigation was launched in July last year, after journalist John Crewdson of the Chicago Tribune alleged that clinical trials involving NIH researchers and carried out in Zaïre and France since 1986 had breached US regulations. The projects examined by OPRR include the much-publicized first human trials of a putative AIDS vaccine, which were carried out in Zaïre and reported in Nature (326, 249; 1987 \& 332, 728; 1988).

OPRR's findings make disturbing reading. NIH failed to make their researchers aware of US Department of Health and Human Services regulations on the use of

\section{Superconducting motor}

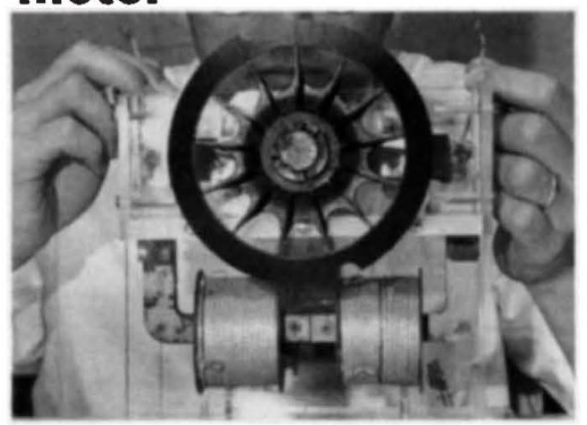

CoILS of a bismuth-based superconductor form the heart of this 25-watt, 0.5-amp motor which powers the small fan above it. "To our knowledge, this is the first time anyone has built a superconducting motor using high-temperature superconducting coils that produces a usable power output," says Gregory Yurek, president of American Superconductor Corporation of Watertown, Massachusetts, which built the coils. Reliance Electric of Cleveland built the motor. Superconducting motors are one of the most potentially important applications of high-temperature superconductors because large motors for industrial and commercial use account for a major portion of all electric power consumption, and even a small increase in motor efficiency could save a lot of money.

R.P. human subjects in clinical trials, the report claims. Researchers collaborating with Zagury were unaware that these rules applied to research carried out abroad as well as in the United States. Consequently, NIH researchers sought the required approval for their research from a review board at their own institutes in only a few of the nine projects examined in the report.

Zagury disputes the OPRR contention that NIH researchers were in fact true collaborators on his projects and thus needed NIH approval (see Nature 352, $180 ; 18$ July 1991), and his lawyer has written to OPRR director Charles McCarthy describing the report as "eminently libelous".

In their official response to OPRR, NIH say that a new Office of Human Subjects Research will in future oversee all research with human subjects, and educate all NIH researchers about relevant regulations. Until earlier this year, this was the responsibility of Saul Rosen, acting director of NIH's Warren Grant Magnuson Clinical Center. OPRR's investigation found that Rosen exerted little authority over NIH researchers outside the clinical centre itself.

Although OPRR reserves its strongest criticism for NIH, the report also singles out Zagury and National Cancer Institute researcher Robert Gallo (who is listed as co-author on 14 of Zagury's publications involving research with human subjects) for their "continuing lack of understanding about Health and Human Services human subjects regulations".

When the Zairrean vaccine trials were first reported in the media, Zagury was portrayed as a hero because he had also injected the vaccine into himself. Only later did it emerge that the "small group of Zaïreans" described in the first Nature paper were children.

The Zaïrean trials relied heavily on technical expertise and materials provided by NIH researchers. In particular, the OPRR report notes that Zaïrean subjects were initially injected with a recombinant vaccinia virus, containing genetic material from human immunodeficiency virus, supplied by National Institute of Allergy and Infectious Diseases researcher Bernard Moss for use in animal research.

The OPRR is reserving its final word on the Zagury affair until it has more information on the extent of any harm suffered by the subjects involved in the various experiments. Three French AIDS patients and one Zaïrean enrolled in immunotherapy trials using the recombinant vaccinia are known to have died, but Zagary maintains that the Zaïrean children involved in the vaccine trials remain healthy.
Peter Aldhous
AIDS DRUGS

\section{DDI nears approval}

\section{Washington}

DIDEOXYINOSINE (DDI) should soon become the second antiviral drug approved by the US Food and Drug Administration (FDA) for use against human immunodeficiency virus (HIV). The Antiviral Drug Products Advisory Committee, an independent panel that advises the FDA, decided last Friday to recommend approval for the drug to treat AIDS patients not responding to treatment with zidovudine (AZT). The FDA is expected to endorse the recommendation.

The advisory committee's 5:2 vote in favour of approval was welcomed by many AIDS activists, who have long argued that the US drug approval process should be streamlined, to counter the AIDS epidemic. That message seems to have been heard by the antiviral advisory committee, which recommended approval for DDI, despite the fact that the data presented by its manufacturer, BristolMyers Squibb, on the efficacy of the drug in fighting AIDS, were far from complete.

Like Wellcome's AZT, DDI slows replication of HIV by inhibiting the enzyme reverse transcriptase. But up to $\mathbf{4 0}$ per cent of patients have to come off AZT after a year of treatment, because of side effects - including nausea and muscle wasting. Viral resistance to $\mathrm{AZT}$ can also occur.

A third reverse transcriptase inhibitor, Hoffmann-La Roche's DDC, is also awaiting FDA approval as an anti-HIV agent. But once this drug is approved, no new AIDS drugs will be approved for several years, unless the current process is reformed.

This time could be reduced, however, by a new proposal for 'accelerated' drug approval, currently being drafted by FDA officials. The new class of approval is expected to apply not only to AIDS drugs, but also to experimental drugs developed to treat other life-threatening or seriously debilitating diseases such as cancer or Alzheimer's. John Petriccani, vicepresident of the Pharmaceutical Manufacturer's Association, says the new proposal, to be announced later this summer, is expected to allow approval without conclusive proof that a drug can extend life, provided that further clinical studies are carried out after the drug is first marketed - in essence, formalizing the process that has happened for DDI.

The AIDS drugs that may be affected by the FDA's fledgling proposal include BI-RG-587, from Boerhinger Ingelheim, and Merck's L-drug. Unlike AZT, DDI and DDC, which were all developed for other purposes before finding a second lease of life as AIDS drugs, this next generation of anti-HIV agents were designed specifically to counter HIV infec-

tion.

Peter Aldhous 